\title{
神経因性膀胱機能障碍の臨床
}

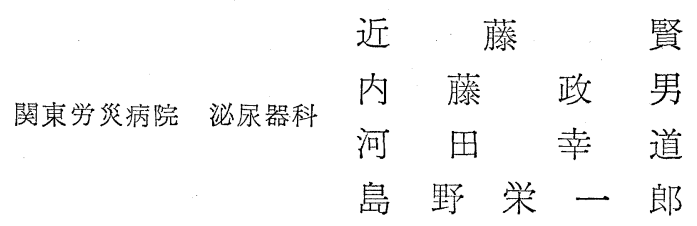

\section{CLINICAL CONSIDERATIONS ON THE NEUROGENIC NEUROMUSCULAR DYSFUNCTION OF BLADDER AND URETER}

\author{
Kondo Masaru, Naito Masao \\ Kawada Yukimichi and, Shimano Eiichiro \\ from the Department of Urology, Kanto-Rohsai Hospital, Kawasaki, Kanagawa
}

\section{I 緒 言}

衸神経因性膀胱機能障碍の弓ち臨床的に重要なものとし て膀胱尿管逆流, 尿失禁, 排尿困難をあげるとこが出来 る. そのうち尿失禁と排尿困難は排尿障碍であり, 膀胱 機能障碍であるととに問題はない. しかし膀胱尿管逆流 注その病因論の立場からほ膀胱機能障碍とはいい難い. ただ尿失禁と同じょうに膀胱内容を膀胱外々もらすとい う点からみれば膀胱の機能障碍とみなすととも可能であ 台.

外傷性脊䯣麻瘦患者におけるこれら 3 者の発生頻度を 当院に入院した患者についてみると, 膀胱尿管逆流は 114症例中18例15\%であり, 尿失禁のはげしいものは58 症例中 17 例 $29 \%$ であり, 排尿困難の強いものは 58 症例中

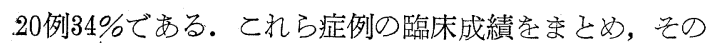
診断, 治療, 発生機序及び今後の問題について考察を 行了.

\section{II 膀胱尿管逆流}

膀胱尿管逆流を如何なる方法で診断し, その方法がど の様な診断的意義をもつかを明らかにするととがその臨 床観察上必要である. 叉本症の治療はその発生機序に対 する見解，腎に及添す影響に関する見解乙密接にむすび ついている. 従つて治療字論ずる場合には発生機序及び 腎障碍との関係に関する検討を除外するととが出来な w.

\section{方法：}

春損患者 114 症例中18例 $15 \%$ 亿膀胱尿管逆流字認めた が, この発生頻度 は Comarr \& Bors 1955の13.3\%,
Bunts 1958 $13.6 \%$, Hoffman \& Bunts 1961 D15\%と 比較して低いものではない. 膀胱尿管逆流の診断は専ら レ線学的所見にもとづいて行なわれる.当院では 150 $\mathrm{ml}$ の造影剂を逆行性に膀胱に注入してから10 20分後 に撮影を 1 回だけ行うという簡単な方法をとつている. 最近では種从の撮影方法が報告されているので, 当院の 撮影方法が膀胱尿管逆流の診断にざの程度の意義をもつ か検討しておく必要がある.

診断的意義：

膀胱尿管逆流活種从の立場から分類されているが, Melick, Brodeur \& Karellos 1962又 Lattimer, Apperson, Gleason, Baker \& Fleming 1963山逆流発生時の膀 胱の容量と内圧から分類を行つている(第 1 表). そうし て両者乞も膀胱容量が小なる時に 発生する逆流 Melick 等 Group 4, 5, 又 Lattimer 等 Group III を最も重症己

第 1 表 「尿管膀胱弁」障碍度に上る分類

\begin{tabular}{|c|c|c|c|}
\hline & Group & Volume & $\begin{array}{l}\text { Intravesical } \\
\text { pressure }\end{array}$ \\
\hline \multirow{5}{*}{$\begin{array}{l}\text { Melick, Brodeur } \\
\text { \& Karellos } \\
1962\end{array}$} & 1 & & raised voiding \\
\hline & 2 & large & low or normal \\
\hline & 3 & normal & elevated \\
\hline & 4 & $\begin{array}{l}\text { extremely } \\
\text { low }\end{array}$ & $\begin{array}{l}\text { low or near } \\
\text { normal }\end{array}$ \\
\hline & 5 & $\begin{array}{l}\text { extremely } \\
\text { low }\end{array}$ & $\begin{array}{l}\text { marked eelvat- } \\
\text { ed }\end{array}$ \\
\hline \multirow{3}{*}{$\begin{array}{l}\text { Lattimer, Ap- } \\
\text { person, Gleason } \\
\text { Baker \& } \\
\text { Fleming } 1963\end{array}$} & $\mathrm{I}$ & & high \\
\hline & II & high & lower \\
\hline & III & low & low \\
\hline
\end{tabular}


し, 所謂尿管膀胱弁の障碍が最も強いとしている. 成人 の膀胱に掞いては容量 $150 \mathrm{ml}$ は小量というととが出来 る. 従つて当院の方法で認めらる膀胱尿管逆流は所謂尿 管膀胱弁の障碍が最も強い型にはいる. 又との方法で膀 胱尿管逆流の認められぬ症例の中には如何に条件をかえ てもそれが発生しないものから, 条件を変更すれば発生 するものまでを含んでいる.しかしたと六条件をかえて 膀胱尿管逆流を認めたとしてもその場合の所謂尿管膀胱 弁の障碍は軽度と考えるととが出来る.

臨床経過：

膀胱尿管逆流を合併した症例の臨床経過をみると18症 例中 12 症例に怙いて膀胱尿管逆流が消失している．尿管 下端形成手術で消失した 2 症例，自然に消失した 4 症 例，薬剂投与で消失した 6 症例，合計 12 症例である.

この経過のうち注目すべきととは 18 症例中 10 症例の膀 胱尿管逆流が手術によらず消失していることである.

発生機序：

膀胱尿管逆流の発生機序 は 尿管下端の受動的弁構造 の異常にもとづくものであるという passive flap valve theory が定説といわれている.しかしこの定説のみでは 説明し難い経過をとる症例のあるととが分つてきた。す なわち前述したように膀胱尿管逆流の中には自然に消失 する症例や自律神経系薬剤で消失する症例がある。

そこで膀胱尿管逆流の発生には器質的要因以外に機能 的要因も関与していると考え，乙の両者の果している割 合いを知る目的で不完全な形ではあつたが自律神経系薬

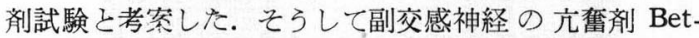
hanechol chloride 或浪㑡剤 Diphemanil methylsulfate の何れかにより $52 \%$ 或は $33 \%$ の膀胱沓管逆流が 明らかな影響をうけるととを認めた。しかも自律神経系 薬剂により膀胱尿管逆流が消失した症例の中に注尿管下 端の解剖学的構造異常を示すレ線像であるという dog ear を明らかに認めた症例もあつた（写真 1 及 2 ).この 様な観察から春損患者の膀胱尿管逆流の主要原因は機能 的異常と考えるに至つた.

生理的に膀胱尿管逆流の発生を防止している機序しし $\tau$ Melick 等1962は Whistle valve theory ens 等1962は Activated flap valve theory を提唱して いる. 又尿管の 逆蠕動 Antiperistalsis of ureter も膀 胱尿管逆流の発生機序として考えられ，動物実験的には 東北大学泌尿器科教室の業蹟があり, 人における尿管の 逆蠕動は Waring 1928, Gruber 1930 Trattner 1930 が指摘し, 最近では Murnaghan 1959, Melick, Nary-
写真 1 Th 12 脱臼骨折（昭和30年12月29日） 昭和 35 年 1 月 22 日撮影 膀胼像 左尿管完全逆流

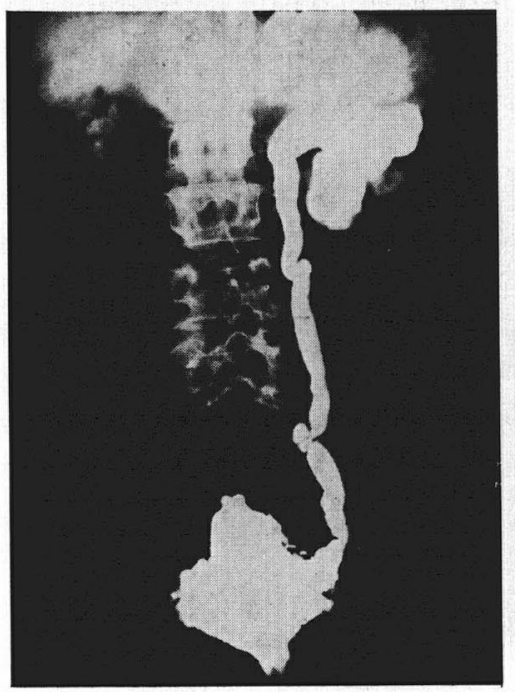

写真 2 Th 12 脱臼骨折（昭和30年12月29日） 昭和 35 年 10 月 28 日撮影 膀胼像逆流消失 (Bethanechol chloride $30 \mathrm{mg} /$ 日 服用中)

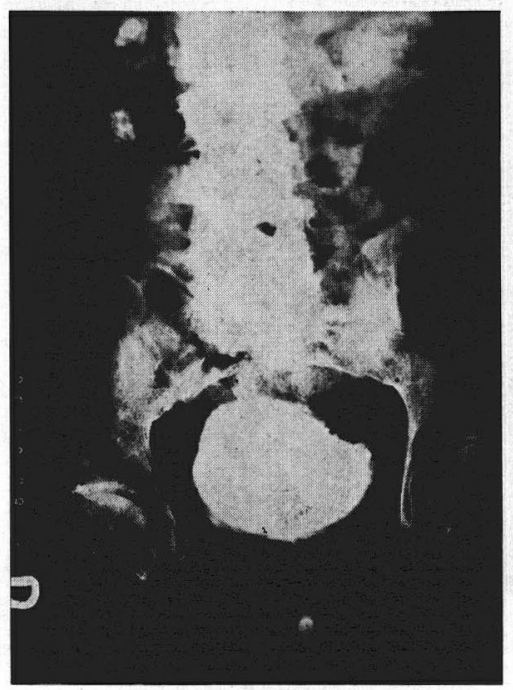

ka \& Schmidt 1961, Hinman, Miller, Hutch, Gainey, Cox, Goodfriend \& Marshall 1962が認めている.

要するに膀胱尿管逆流の発生機序は静的な所謂尿管膀 胱弁の器質的異常によるという考え方から動的な尿管の 機能異常によるという考え方に変つてきて㧍り，われわ れの臨床観察の結果もそれを支持している。 このような 
写真 3 L 1 脱臼骨折 (昭和 29 年 7 月 7 日) 昭和33年 8 月 27 日撮影 排泄性腎孟像

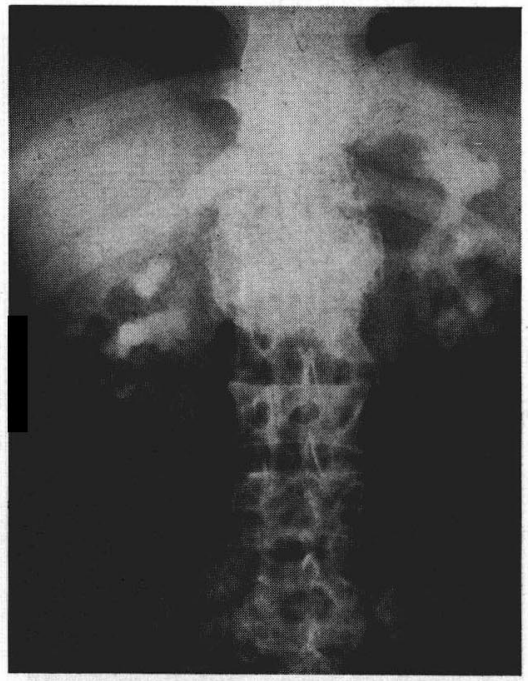

写真 4 L 1 脱臼骨折（昭和 29 年 7 月 7 日） 昭和33年 8 月 28 日撮影 膀胼像

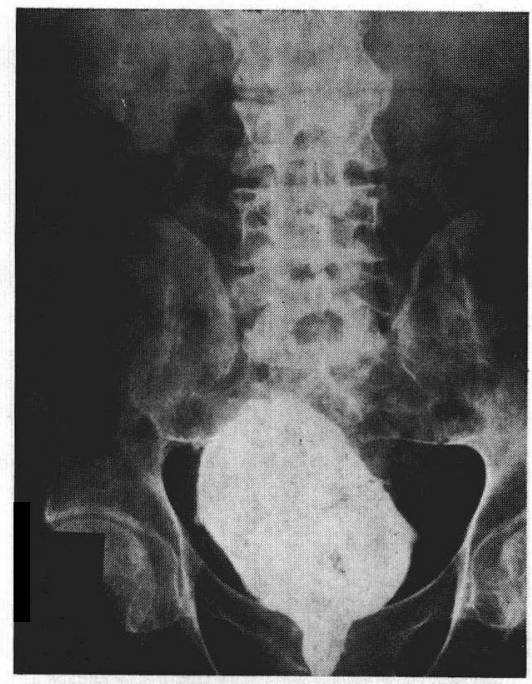

発生機序の考え方の変化は当然治療面に大きな变化字も たらしてくる.この点については後述する。

腎障碍：

膀胱尿管逆流と患側腎の障碍が同時に認められること は屡々あり，そのような場合膀胱尿管逆流はその腎障碍 の原因と考えられている.

この考え方と Passive flap valve theory を根拠とし て尿管下端の弁再建の形成手術が唯一の積極的治療法と
写真 5 L 1 脱臼骨折（昭和29年 7 月 7 日） 昭和35年 6 月 28 日撮影 膀胱像

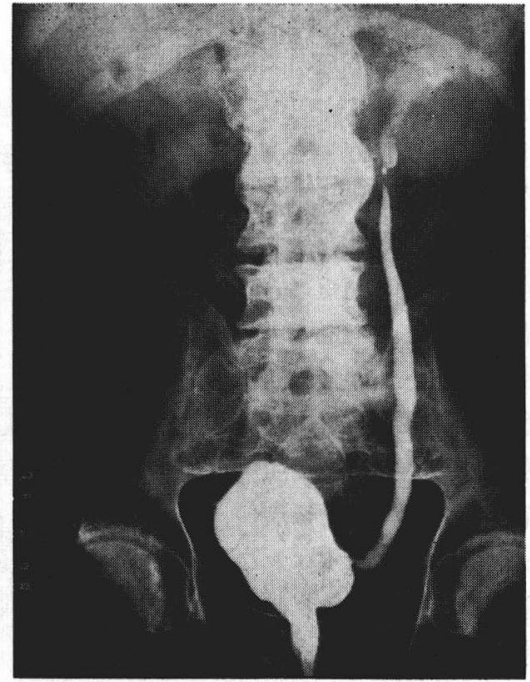

写真 6 L 1 脱臼骨折（昭和 29 年 7 月 7 日） 昭和35年 7 月14日撮影 排泄性腎盂像

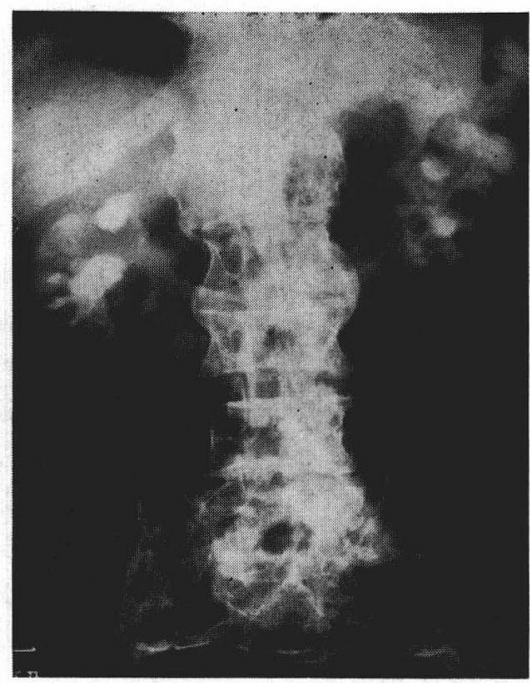

して行なわれてきている. しかし果して膀胱尿管逆流は 常に患側腎の障碍の原因なのであろろか。臨床観察によ ると膀胱尿管逆流が腎障碍の原因々考え難い症例 があ る. 例えば第 1 腰椎骨折（昭和 29 年 7 月 7 日）の症例で 初診（昭和 33 年 8 月下旬）以受傷後 4 年 1 月を経過して いた。 その当時逆流はなく(昭和 33 年 8 月 28 日, 写真 4 ), 両腎こも腎孟桩大，造影剂排出低下がみとめられた（昭 和 33 年 8 月 27 日, 写真 3 ). 受傷後 6 年左膀胱尿管逆流肎 
発見し（昭和 35 年 6 月 28 日, 写真 5 ), その時にも腎障碍 (写真 6 ) が受傷後 4 年 1 月（写真 3 ) と同じ様に存在 していた. もし当院受診が受傷後 6 年であつたならばこ つ症例の左腎障碍は左膀胱尿管逆流にもとづくものと考 えるのが定説的見解であろう.しかし実際にはその腎障 碍は膀胱尿管逆流発生以前にすでに存在していたのであ る. 従つて, 膀胱尿管逆流腎障碍の主要原因已考元る 定説的考え方は余り妥当なものではないようである.

東北大学泌尿器科教室の動物実験によれば膀胱支配神 経損傷により膀胱から腎孟・腎実質に及ぶ尿路の激しい 炎症性変化が認められるという. この実験に似た状態が 春損患者にも抬きているとすると, 春損患者の腎の障碍 は膀胱尿管逆流々は無関係に発生してくると考えれる. そうして膀胱尿管逆流は腎に対して悪影響を与えるとし ても, その主要原因でない場合が相当に多く, 臨床的に は上部尿路障碍の存在を示す重要な症状にすぎないと考 える方が妥当と思われる.

治療：

膀胱尿管逆流の主要原因が尿管の機能異常である己考 えると, その機能異常は自律神経系薬剤或いは尿管平滑 筋の代謝異常を是正する薬剤投与で治療する可能性が考 えられる。

われわれはかかる見解ともとづいて Bethanechol chloride, Propanthelin bromide, Anabolic steroid, ATP, $\alpha$-Tocopherol, Asparagic acid, AICA orotate 及び cytochrome c の8 剂の投与を試み, Bethanechol chlo. ride 投与で 3 症例, $\alpha$-Tocopherol 投与で 2 症例, AICA orotate 投与で 1 症例, 合計 6 症例に膀胱尿管逆流の消 失を認めた (第 2 表).

\section{第 2 表 膀腅尿管逆流の治療}

(1) 薬物療法 Bethanechol chloride Propanthelin bromide Anabolic steroid ATP

$\alpha$ Tocopherol Asparagic acid AICA orotate Cytochrome c

(2) 形成手術

膀胱尿管逆流の発生機序が尿管の機能異常にもとづ き, その神経筋肉性異常 neuromuscular ureteral dysfunction を是正することを目的とする薬物療法怯われ われの調べた限りに执いては尿管下端の限局性炎症にも
とづく浮腫を除去する目的で行なわれる抗菌剤投与を除 いて文献上飞見出しえない. しかしかかる薬物療法は今 後尿管の生理, 病理或いは薬理が解明されるに従つて進 悲し, 膀胱尿管逆流の治療の中心をなすであろろと期待 される.

尿管下端の受動的弁の 形成術 は passive flap valve theoryが屍体については正しいことから考えて臨床的に も完全に否定されるととはないであろう。しかし臨床的 には尿管自体の機能の方が主要な役割りを果して拉り, 且つ膀胱尿管逆流が患側腎の障碍の主要原因ではなく単 なる合併症状にすぎない場合があるという 2 点から考え て, この形成手術を行う際にはその適応を慎重に検討す べきである. かかる検討を行なわずとこの種の形成手術 を行うととは Comarr 1959, Melick, Brodeur \& Karellos 1963が指摘しているょうに改めるべきととであ る.

\section{排尿障碍}

脊損患者の排尿障碍は受傷後の 経過年数, 受傷の 部 位, 程度及び型, 膀胱容量と密接な関係をもつと考えら れる. そこで昭和 38 年 5 月当院入院中の脊損患者 58 症例 について調査した排尿障碍の種類及び程度とそれらとの 関係学検討してみた。.

排尿障碍は排永困難己尿失禁己に分けたが，排尿困難 の中には残尿の多い尿閉の型さ, 残尿は少いが, そとま で排尿するのに非常な努力と時間を要する型との 2 者が 含まれている.

受傷後年数：

受傷後経過年数己排尿困難己の関係学排尿困難の強い 20 症例についてみると 1 年未満では $75 \%$ と高率である が, 1 〜 年では $9 \%$ と著明に減少している(第3 表). これは 1 年末満の急性期には受傷部位, 程度と関係なく 全ての症例に尿閉が执きてくること, 又 $1 \sim 2$ 年の回復 期に执いては尿閉に対与る治療が充分な効果をあらわし ていることを示している. しかし 1 且回復した排尿機能 がその後年月の経過とともに悪化する傾向がみられ，そ の発生頻度は16\%，33\%，47\% 次第に増加している (第3 表). 尿失禁の激しい17症例についてみると 1 年未 満には 1 例もなく, $1 \sim 2$ 年に执いて又 3 年以後に掞い て31〜41\%の頻度でみられる. しかし排尿困難のように 次第にその発生頻度が増加してゆく傾向は認められない

(第 3 表).

受傷部位及び程度：

受傷直後の排尿困難は損傷部位とは無関係に発生する 
第 3 表 排尿障害と受傷後年数

\begin{tabular}{|c|c|c|c|c|c|c|c|c|c|c|c|}
\hline \multirow{2}{*}{ 受傷後年数 } & \multirow{2}{*}{ 症例 } & \multicolumn{5}{|c|}{ 排 尿 困 難 } & \multicolumn{5}{|c|}{ 尿失 禁 } \\
\hline & & $\begin{array}{l}\text { 完全 } \\
\text { 弛緩 }\end{array}$ & $\begin{array}{l}\text { 不完 } \\
\text { 弛緩 }\end{array}$ & $\begin{array}{l}\text { 不完 } \\
\text { 㾤变 }\end{array}$ & \multicolumn{2}{|c|}{ 計 } & $\begin{array}{l}\text { 完全 } \\
\text { 驰緩 }\end{array}$ & $\begin{array}{l}\text { 不完 } \\
\text { 弛緩 }\end{array}$ & $\begin{array}{l}\text { 不完 } \\
\text { 痙挛 }\end{array}$ & \multicolumn{2}{|c|}{ 計 } \\
\hline$\sim 1$ 年 & 4 & 2 & & 1 & $3 / 4$ & $75 \%$ & & & & $0 / 4$ & \\
\hline $1 \sim 2$ 年 & 11 & & & 1 & $1 / 11$ & $9 \%$ & 4 & & & $4 / 11$ & $36 \%$ \\
\hline $2 \sim 3$ 年 & 6 & & 1 & & $1 / 6$ & $16 \%$ & & & & $0 / 6$ & \\
\hline $3 \sim 4$ 年 & 6 & & & 2 & $2 / 6$ & $33 \%$ & 2 & & & $2 / 6$ & $33 \%$ \\
\hline $4 \sim 5$ 年 & 12 & 1 & & 3 & $4 / 12$ & $33 \%$ & 2 & & 3 & $5 / 12$ & $41 \%$ \\
\hline 5 年〜 & 19 & 1 & 1 & 7 & $9 / 19$ & $47 \%$ & 2 & & 4 & $6 / 19$ & $31 \%$ \\
\hline 計 & 58 & 4 & 2 & 14 & $20 / 58$ & $34 \%$ & 10 & 0 & 7 & $17 / 58$ & $29 \%$ \\
\hline & & ${ }^{4} / 30$ & & ${ }^{16} / 28$ & & & ${ }^{10} / 30$ & & $7 / 28$ & & \\
\hline & & $13 \%$ & & $57 \%$ & & & $33 \%$ & & $25 \%$ & & \\
\hline
\end{tabular}

第 4 表 排尿障害と受傷部位

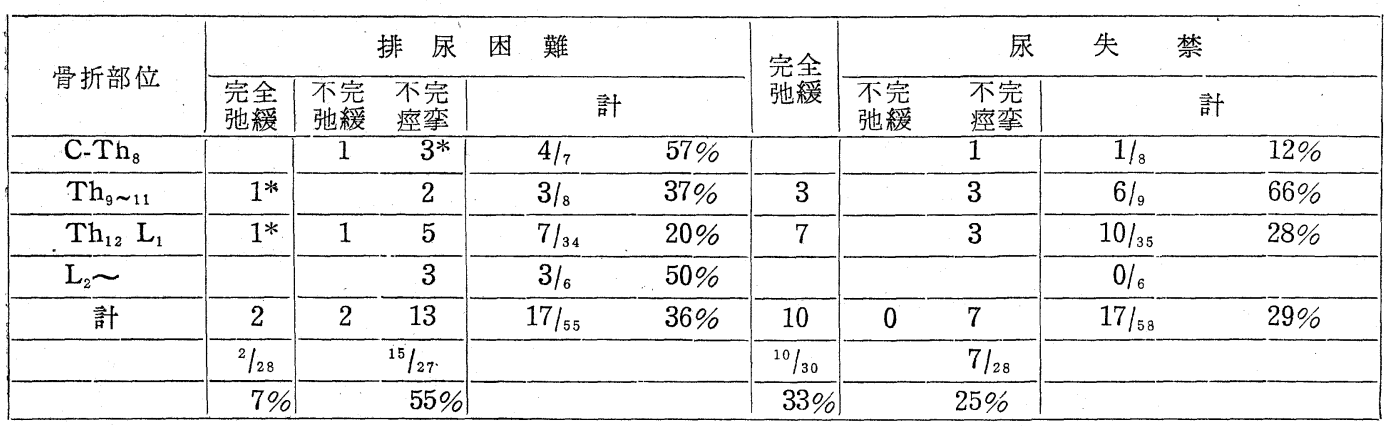

* 受傷後 1 年未满の症例 3 例除外

ので受傷後 1 年未満の 3 例を除き, 排尿困難17例, 尿失 禁17例についてその受傷部位別の発生頻度をみると排尿 困難では䅡椎骨折が，尿失禁では第 $9 \sim 11$ 胸椎骨折が最 も高率である(第 4 表).

整形外科的に脊䯣損傷の程度及び型を分類すると完全 損傷は 58 症例中 30 症例ですべて弛緩麻疸であり, 不完全 損傷は58症例中 28 症例であり, そのうち 2 例以外怯すべ て痓攣性麻疩である(第 3,4 表).

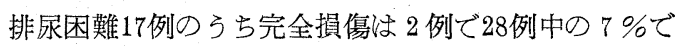
者り，不完全損傷は15例で27例中の $55 \%$ 占めている

(第 4 表). 尿失禁17例のう 与完全損傷は10例で30例中の $33 \%$ ありり, 不完全損傷は 7 例で 28 症例中の $25 \%$ ある (第 3,4 表).從つて排尿困難柱不完全損傷の病卛麻瘦 の患者に多発する傾向がみられるが，尿失禁ば損傷程度 による差異は殆んご認められない。

膀胱容量 :

排尿障碍と膀胱容量との関係を検討する際に問題とな るのは脊損患者の膀胱容量の測定方法である. 逆行性に
液を注入し, その注入量学膀胱容量とすることは脊損患 者については適当でない, そこで 1 回の最大排尿量をそ の膀胱容量と夕なし，200 $\mathrm{ml}$ 以下，200〜 $300 \mathrm{ml}, 300$ $\mathrm{ml}$ 以上と大別してみた.

58 症例中尿道カテーテル留置を行つている 7 症例安除 いた 51 症例を膀胱容量別に分類すると $200 \mathrm{ml}$ 以下 19 症 例, $200 \sim 300 \mathrm{ml} 18$ 症例, $300 \mathrm{ml}$ 以上 14 症例となる

(第 5 表). 奉䯣損傷程度による膀胱容量の差は認められ ず，損傷部位別にみると $200 \mathrm{ml}$ 以下症例では高位損傷 漂ど発生が高く, $300 \mathrm{ml}$ 以上では低位損傷湒ど発生頻 度が高い (第 5 表).

膀胱容量と排尿障碍との関係をみると排尿障碍のひざ 心症例（第6表 (D) + (I) + (D+I) ) 住 200 $\mathrm{ml}$ 以下では68\%，200〜 $300 \mathrm{ml} て ゙ は 44 \% ， 300 \mathrm{ml}$ 上では $35 \%$ である。すなわち膀胱容量が小さい隍で排尿 障碍の合併率が高い.

排尿困難と尿失禁己を分けてそれぞれの発生頻度をみ ると排尿困難の症例 (第 6 表 $(D)+(D+I))$ は膀 
第 5 表 膀脱容量と受傷部位

\begin{tabular}{|c|c|c|c|c|}
\hline \multirow{2}{*}{ 骨折部位 } & \multirow{2}{*}{ 症例 } & \multicolumn{3}{|c|}{ 最大 1 回排尿量 } \\
\hline & & $\sim 200 \mathrm{ml}$ & $\begin{array}{l}200 \sim \\
300 \mathrm{ml}\end{array}$ & $300 \sim \mathrm{ml}$ \\
\hline $\mathrm{C}^{-\mathrm{Th}_{8}}$ & 4 & $3 \quad 75 \%$ & $1 \quad 2 b \%$ & 0 \\
\hline $\mathrm{Th}_{9}-11$ & 8 & $4 \quad 50 \%$ & $337 \%$ & $112 \%$ \\
\hline $\mathrm{Th}_{12} \mathrm{~L}_{1}$ & 33 & $1133 \%$ & $13 \quad 39 \%$ & $927 \%$ \\
\hline $\mathrm{L}_{2} \sim$ & 6 & $116 \%$ & $116 \%$ & $466 \%$ \\
\hline 計 & 51 & 19 & 18 & 14 \\
\hline
\end{tabular}

第 6 表 膀胱容量と排尿障碍

\begin{tabular}{|c|c|c|c|}
\hline & $\widetilde{2} \underset{19 \text { 例 }}{200 \mathrm{ml}}$ & $\begin{array}{c}200 \sim 300 \\
\mathrm{ml} 18 \text { 例 }\end{array}$ & $\begin{array}{c}300 \mathrm{ml} \sim \\
14 \text { 例 }\end{array}$ \\
\hline 排尿困難（D） & 3 & \begin{tabular}{|l|l|}
3 \\
\end{tabular} & 3 \\
\hline 尿 失禁 (I) & 8 & 4 & 1 \\
\hline 谣発 $(D+I)$ & 2 & 1 & 1 \\
\hline$(I)+(D+I)$ & $13 / 19$ & $8 / 18 \quad 44 \%$ & $5 / 14 \quad 35 \%$ \\
\hline $\begin{array}{l}\text { 排尿困難 (D)+ } \\
(\mathrm{D}+\mathrm{I})\end{array}$ & $5 / 19 \quad 26 \%$ & $4 / 18 \quad 22 \%$ & $4 / 14 \quad 28 \%$ \\
\hline $\begin{array}{l}\text { 尿失禁（I ）+ } \\
(\mathrm{D}+\mathrm{I})\end{array}$ & $10 / 19$ & $5 / 18$ & $2 / 14 \quad 14 \%$ \\
\hline
\end{tabular}

胱容量と致ん己゙関係なく22２8\%である．ところが尿 失禁の症例（第 6 表 $(I)+(D+I))$ は $200 \mathrm{ml}$ 以 下では52\%，200〜 $300 \mathrm{ml} て ゙ は 27 \% ， 300 \mathrm{ml}$ 以上で

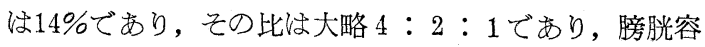
量 $200 \mathrm{ml}$ を境として, それ以下の症例に激しい㽷失禁 が多発する傾向を認めることが出来る.

考察:

排尿障碍の機序は排尿困難にせよ尿失禁にせよ図式化 して膀胱内压々下部尿路抵抗との相関関係兮ら考えるこ とが出来る. 膀胱内圧は利尿筋と腹圧とにより決まり, 下部尿路抵抗は膀胱三角部々前立腺部尿道に扣ける抵抗 により決まり，乙の両者の組合せにより臨床上の種なの 障碍が説明可能である.

受傷後 1 年未満の排尿困難は膀胱の低緊張と三角部に 招ける抵抗とが重要な因子となつている，乙の考え方に もとづき回復期の排尿困難の治潦として膀胱内压を上昇 させる排尿訓練及び薬物療法, 三角部抵抗を除去する尿 管口間䩲帯或いは膀胱碩部の経尿道的電気切開を行つて いる. かかる治療方針及び方法の効果は受傷後 $1 \sim 2$ 年 の排尿困難 $9 \%$ (第 3 表) という数值で示されて招り, これはその正当性を裏付けている。

受傷後 2 年以上を経過すると排尿困難は再びその発生 頻度を增してくる. この時期の排尿困難の多くが不完全 損傷痤卛麻疩患者に合併すること考えると，加る排
尿困難の最も重要な因子は外尿道括約筋の痤卛にもとづ く下部尿路抵抗の增大であると推測される. 従つて慢性 期つ排尿困難の治療は外尿道括約筋の病攣学已める薬物 療法或恃神経外科的手術, 又痤攣する括約筋を切除する 経尿道的手術によらねばならぬ.

尿失禁は排尿困難と異なり患者の生命に值接関係しな いことから従来無視される傾向にあつた。 しかし春損患 者の社会復帰を考える時には決して無視出来ない問題て ある. この尿失禁は受傷後 1 年未満にはなく, 受傷後年 “数を経るに従つて增加する傾向もなく, 又損傷程度, 麻

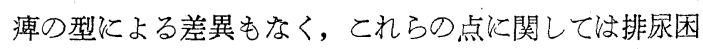
難と全く異つている．そうして激しい尿失禁が膀胱容量 $200 \mathrm{ml}$ 以下の症例に多発する傾向があることが分つた ので，乙の特徵を手がかりとして脊損患者の尿失禁の問 題を更に検討することにした。

\section{Cystoadaptometry}

脊髄損傷に合併して膀胱に拉きてくる最も著明な変化 は膀胱内容量の增加に対して利尿筇が迅速に適応するて とが出来なくなることである (Emmett 1957).従来の 逆行性或渄泄性の膀胱内压測定法が各从それなりの意 義学もつととは確かであろろが，それらにより利尿筋の 適応能力の障碍程度を知るととは出来ない。しかし春損 患者の排尿障碍の発生機序に执いて利尿筋の適応能力の 障碍が相当重要な役割りを果していることは当然予想さ れる. そこで利尿筇の適忘能力の障碍程度を知るととを 目的とした検查方法学考元, Cystoadaptometry 已名付 けた. かかる膀腅の適応能力の測定に関する具体的方法 としては Arnold 1959の Vesical adaptometer という 報告がある．その方法を参考にし，春損患者の膀胱容量 が $200 \mathrm{ml}$ 以下になると激しい尿失禁台合併する率が急 に高くなるととを考慮にいれ，Cystoadaptometry とし て次のような測定方法を行つた。

方法：

液温 $30^{\circ} \mathrm{C}$ 3000 倍モナフラシン液 $200 \mathrm{ml}$ を 45 秒間に 膀胱内に逆行性に注入し，乙の急速な容量増加に対して 利尿筋がいかに適応するかを $200 \mathrm{ml}$ 注入直後から膀脱 内圧測定学行つて判定した．乙の場合の膀胱内圧の変動 は武井医科光器製作所に依頼作製した膀腅内圧自動記録 装置を用いて記録した。

正常範囲 :

従来の逆行性膀胱内圧測定で膀胱容量 $200 \mathrm{ml}$ 㭙の正 常内圧の範囲が 1 ～10mm Hgであるととから，上記の方法 で測定を行つた場合の正常範囲を $200 \mathrm{ml}$ 注入終了後 1 
第 7 表 膀脱内圧と膀脱容量

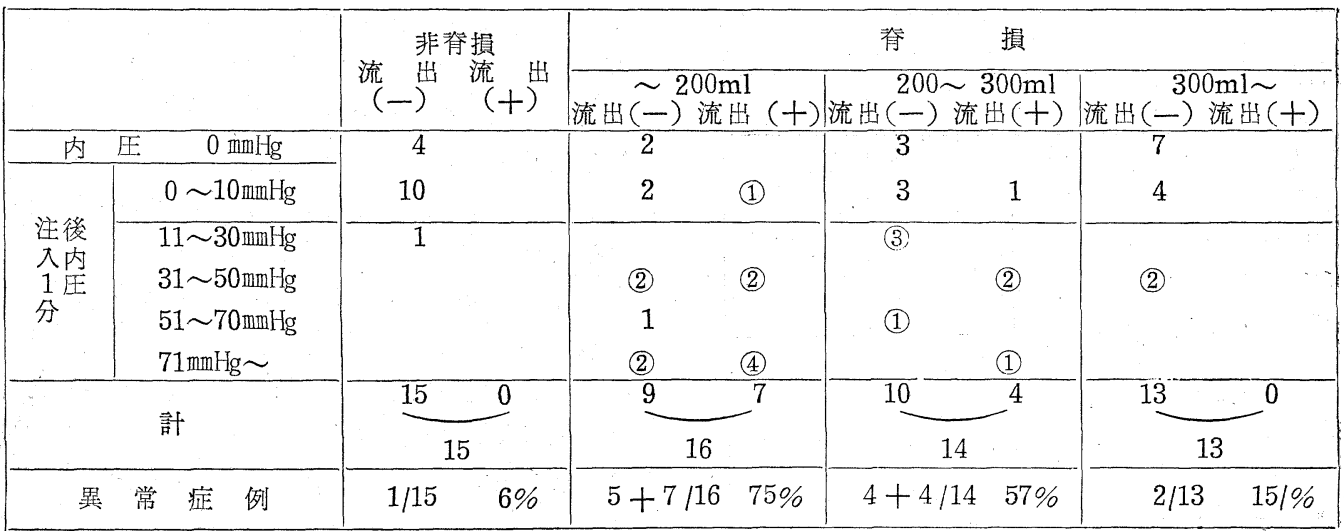

分厅内に，その内圧が10 $\mathrm{mm} H \mathrm{Hg}$ 乃至それ以下となる場合と した.

非脊損患者15症例, 脊損患者 43 症例について Cystoadaptometry を行つた. 正常と判定された症例は前者 15 症例中 14 例 $94 \%$ あ゙り，脊損患者 43 症例中 21 例 $49 \%$ あ つた (第 7 表).

上記の基準で正常と判定された内圧曲線の実例を示せ ばa注内圧 $0 \mathrm{~mm} H \mathrm{Hg}$ (第 7 表) こ分類した症例であり, 注

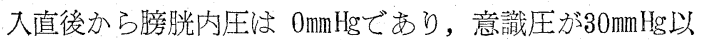
上あるとと示している(第1図).

注入 1 分後の膀胱内圧が $10 \mathrm{~mm} H \mathrm{Hg}$ 万至乞れ以下の場合の 内圧曲線に活種々㐫り第 1 図の b, 第 2 园の $\mathrm{c}, \mathrm{d}$ がその 例である. 曲線bでは注入直後 $2 \mathrm{~mm} H \mathrm{HC゙}$ ，それが 1 分後 まで続いている. 曲線 c は注入直後 $30 \mathrm{~mm} H \mathrm{Hg}$ あるがその 後低下して 1 分後には10mmH以下になって招り, 曲線d では注入直後 $20 \mathrm{~mm} \mathrm{Hg} ゙$ あるがその後膀胱内压の低下上昇

\section{第 1 図}

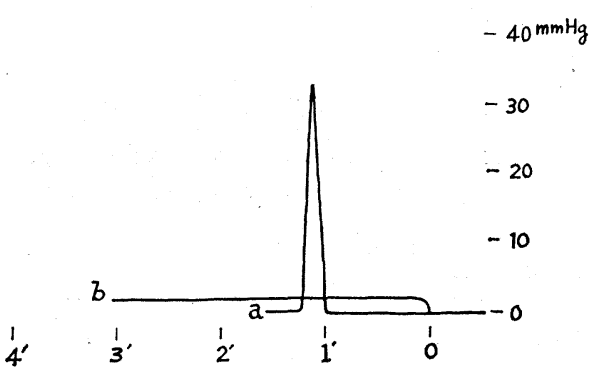

a : $\mathrm{L}_{1}$ 脱臼圧迫骨折 完全損傷，弛緩麻瘦 36. 9. 4. (受傷後 $1 \sim 2$ 年)

b : $\mathrm{L}_{1}$ 圧迫骨折 完全損傷 弛綏麻疾 38. 5.29 . （受傷後 $2 \sim 3$ 年）
第 2 図

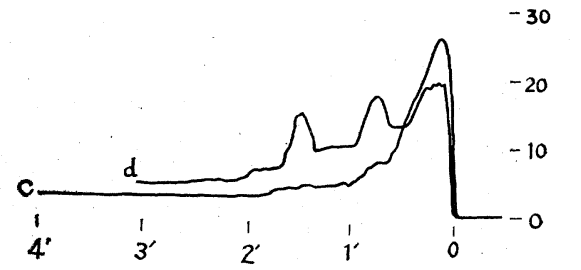

c : $\mathrm{Th}_{7-9}$ 脱臼骨折 完全損傷 弛緩㾁痺 33. 10. 2. (受傷後 $4 \sim 5$ 年)

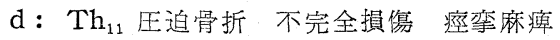
30. 12. 10. (受慯後 $7 \sim 8$ 年)

をくりがしている。しかし1分後に怙ける膀胱内圧は $10 \mathrm{~mm} H \mathrm{~g}$ である.

異常症例：

$200 \mathrm{ml}$ 注入 1 分後の内圧が $11 \mathrm{~mm} H \mathrm{H}$ 以上の場合と 200 $\mathrm{ml}$ を注入しているうちに或柱入直後に或は注入終了 後ある時間を㧈いてから注入液の流出がみられる場合を 異常と判定した. 加る異常症例は非脊損患者15例中 1 例 $6 \%$ 脊損患者 43 例中 22 側 $51 \%$ であつた. 後者のうち膀 胱容量 $200 \mathrm{ml}$ 以下の16症例中異常症例は 12 例 $75 \%$ あ り, $200 \sim 300 \mathrm{ml}$ の14症例中 8 例 $57 \%, 300 \mathrm{ml}$ 以上の 13 症例中 2 例 $15 \%$ ある(第 7 表).すすなお膀胱容量 200 $\mathrm{ml}$ 以下の 症例では適応能力の低下が強く, 所謂過緊張 膀胱である. このことと膀胱容量 $200 \mathrm{ml}$ 以下の症例に 激しい尿失禁が多発するこ己（第 6 表）亡の間仙相関関 係があるか否かを確かめるために第 7 表中の丸印をつけ た異常症例20例に利尿筇の適応能力の改善を試及た. こ の 20 症例中半数の 10 例注入液の流出がない型であり, 
第 8 表 膀腃適応能力の改善

\begin{tabular}{|c|c|c|c|c|c|c|c|}
\hline & \multirow{2}{*}{$\begin{array}{c}\text { Vitamin } \mathrm{B}_{1} \\
150 \mathrm{mg} / \text { 日 } \\
3 \text { 週 }\end{array}$} & \multirow{2}{*}{$\begin{array}{c}\text { Vitamin E } \\
600 \mathrm{mg} / \text { 日 } \\
3 \text { 週 }\end{array}$} & \multicolumn{2}{|c|}{ Bethanechol chloride } & \multirow{2}{*}{$\begin{array}{c}\text { Propanthel- } \\
\text { in bromide } \\
45 \mathrm{mg} / \text { 日 } \\
1 \text { 週 }\end{array}$} & \multicolumn{2}{|c|}{$250 \mathrm{c} / \mathrm{s} \quad 6 \mathrm{~mA}$} \\
\hline & & & $\begin{array}{c}60 \mathrm{mg} / \mathrm{\theta} \\
1 \text { 週 }\end{array}$ & $\begin{array}{c}30 \mathrm{mg} / \text { 目 } \\
1 \text { 週 }\end{array}$ & & 陽刺 5 日 & 陰判 5 日 \\
\hline 流出 (一) 10 例 & $5 / 6$ & $7 / 15$ & $0 / 7$ & $0 / 3$ & $3 / 6$ & $5 / 10$ & $2 / 5$ \\
\hline 流出 (十) 10例 & $1 / 10$ & $5 / 20$ & $0 / 7$ & $0 / 4$ & $2 / 10$ & $2 / 13$ & $2 / 9$ \\
\hline \multirow{2}{*}{ 有效例 計 } & $6 / 16$ & $12 / 35$ & $0 / 14$ & $0 / 7$ & $5 / 16$ & $7 / 23$ & $4 / 14$ \\
\hline & $37 \%$ & $29 \%$ & 0 & 0 & $31 \%$ & $30 \%$ & $28 \%$ \\
\hline
\end{tabular}

残る半数の10例は流出の認められる型であつた。

適応能力の改善 :

神経障碍による利尿筋の適応能力の低下が如何なる方 法で改善されるか全く不明である. そこで東北大学泌尿 器科教室の動物実験の成績に示されている神経障害によ り発生する利尿筋の組織代謝の異常がその適応能力低下 の重要な原因ではないかと考光た。 そこで利尿筇の組織 代謝の異常が是正されれば適応能力の改善がえられるの ではなからうかと考えた。 かかる想定のもとにVitamin $B_{1} 150 \mathrm{mg} /$ 日21日間, Vitamin E 600m/日21日間, Bethanechol chloride 30 60mg/日 1 週間, Propanthelin bromide $45 \mathrm{mg} /$ 日 7 日間, 低周波陽極刺战及㓌極刺㦸各 5 日間守試及た。そうして Cystoadaptometry 上の改善 の有無定検査した。第 8 表中の分母治治療安行つた症例 数であり, 分子は Cystoadaptometry の成績学比較し て膀胱の適応能力の改善がえられたと判定され症例数 である。すなうち Vitamin $\mathrm{B}_{1}$, Vitamin E, Propanthelin bromide，低周波電気刺战に扑てて何れも約30\% の症例に改善を認めたが, Bethanechol chloride に掠 いては 1 日投与量が $30 \mathrm{mg} て ゙ も 60 \mathrm{mg} て ゙ も 1$ 例の改善も認め られなかつた(第 8 表).これはすでに Lapides, Friend Ajemian \& Reus 1962が指摘したことである.

Cystoadaptometry 上の改善が如何なるものかを第 3 図に示す。治療前には $160 \mathrm{ml}$ 注入時より注入液の流出 がはじまり, 注入終了直後の膀胱内圧は70mmHg上であ り， $165 \mathrm{ml}$ が流出して約 3 分後に $10 \mathrm{~mm} H \mathrm{H}$ 以下となつて いた. 治療後には流出は全くなく, $200 \mathrm{ml}$ 注入直後の 膀脱内圧は $5 \mathrm{~mm} H \mathrm{Hg}$ あり，正常と判定された。 臨床的意義：

Cystoadaptometry 上の改善のえられた15症例中明ら かな尿失禁の改善が認められたのは 7 例 $46 \%$ ある（第 9 表). Cystoadaptometry 上の改善がえられた症例の 約半数に尿失禁の明らかな改善が認められたことは慢
第 3 図

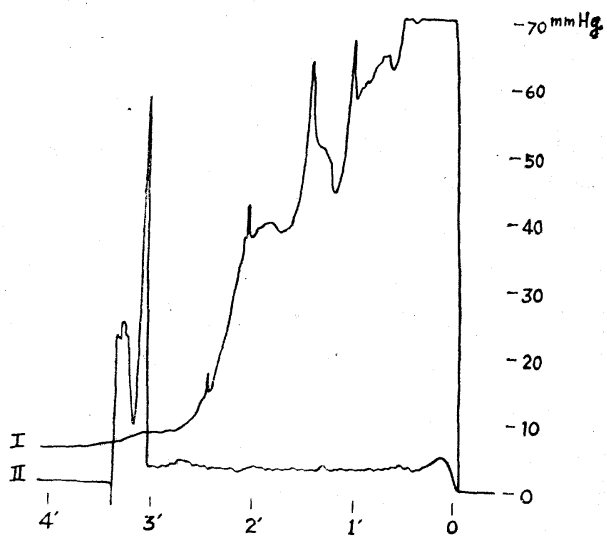

$\mathrm{Th}_{12}$ 圧迫骨折 完全損傷 弛緩麻痺 36.9 .22 .

I $160 \mathrm{ml}$ より流出開始 流出量 $165 \mathrm{ml}$

II 流出 (一)

第 9 表 Cystoadaptometry の臨床的意義

\begin{tabular}{|c|c|c|c|c|}
\hline & $\begin{array}{l}\mathrm{CAM} \\
\text { 改善 }\end{array}$ & $\begin{array}{l}\text { 尿失禁怔 } \\
\text { 尩夜 }\end{array}$ & $\begin{array}{r}\text { 善 }(+) \\
\text { 夜の }\end{array}$ & $\begin{array}{c}\text { 失禁改善 } \\
(\text { (一) }\end{array}$ \\
\hline 流出（一）10例 & 9 & 2 & 2 & 5 \\
\hline 流出 (十) 10例 & 6 & 2 & 1 & 3 \\
\hline 計 & 15 & 4 & 3 & 8 \\
\hline 有 効 & & $7 / 15$ & $46 \%$ & \\
\hline
\end{tabular}

性期脊損患者の尿失禁の原因として利尿筋の適応能力低 下，所謂過緊張膀胱が大をく関与していることを示して いる.

又利尿筋の適応能力低下 が Vitamin $\mathrm{B}_{1}, \mathrm{E}$, Propanthelin bromideの如き薬凪投与で, 或は低周波電気刺战 で改善正常化されることは, 従来怯不完全損傷をうけた 神経による異常刺㦸にもとづくといわれ，又原因不明と いわれてきている所謂過緊張膀胱の発生機序の解明に重 要な示唆を与えるものと思われる。 
尿失禁のほげしい17症例中 7 例約 40\%がかかる方法で 改善されたが，残る10例にはこれらの方法梳何らの改善 をもたらさなかつた，更に又春損患者の尿失禁には覚醒

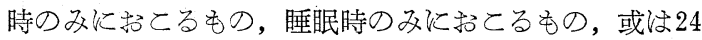
時間同じように括しるもの等の差異があることから考え て, 尿失禁の発生機序には利尿筋の適応能力の低下以外 に膀脱内圧々下部尿路抵抗との相関関係，その間の運動 機序等検索せるね攼ならぬ問題が山積しているととは明ら 亦であり，それらは今後の研究をまつ以外にはない。

\section{結 語}

脊損患者に合併する膀胱尿管逆流, 尿失禁, 排尿困難 についてわれわれの行つている検査, 診断, 治療法を述 べ, その発生機序の考察を行い, 今後の問題について言 及した。 そうしてその何れの障碍も神経障碍によりひき 㧍こされてきたものである故に神経因性とよぶのはよい が, 臨床的に抬きている障碍の原因は神経筋肉性の機能 異常である点で何れも共通している. 従つててれらの臨 休に拀いて注単に神経因性膀胱 neurogenic bladder 考えるょりは神経因性神経筋肉性, 膀胱尿管機能異常 neurogenic neuromuscular vesical and ureteral dysfunction と考える必要がある.それ故それらの治療方針 も先ず neuromuscular dysfunction を是正する保存的 薬物療法を中心を卞べきであり, 外科的方法は適応を慎 重に検討した後に行われるべきものと思われる。

本稿の要旨は日本泌尿器科学会第28回東部連合地方会 に括汸る特別講演において発表した。

\section{文献}

1) Arnold: J. Urol., 82, 651, 1959.

2) Band: Brit. J. Urol., 33, 361, 1961.

3) Bischoff: Brit. J. Urol., 29, 416, 1957.

4) Bohne, Urwiller \& Armento: J. Urol., 86, 548, 1961.

5) Bors: Urol. Surv., 7, 177, 1959.

6) Bors, Comarr \& Moulton: J. Urol., 63, 653, 1950.

7) Bunge: J. Urol., 70, 729, 1953.

8) Bunts: J. Urol., 79, 747, 1958.

9) Comarr: Brit. J. Urol., 31, 1, 1959.

10) Comarr: J. Urol., 83, 34, 1960.

11) Comarr \& Bors: J. Urol., 74, 59, 1955.

12) Edelbrock: J. Urol., 74, 492, 1955.

13) Emmett: Campbell's Urology, p. 1359, W.B. Saunders Company, 1957, Philadelphia \& London,

14) Forsythe \& Whelan: Brit. J. Urol., 30, 189, 1958.
15) Forsythe \& Wallace: Brit. J. Urol., 30, 297, 1958.

16) Garrett, Rhamy \& Carr: J. Urol., 87, 350, 1962.

17) Griffiths \& Walsh: Brit. J. Urol., 33, 374, 1961.

18) Gross \& Sanderson: Radiol., 77, 573, 1961.

19) Gruber: J. Urol., 21, 567, 1929.

20) Gruber: J. Urol., 22, 275, 1929.

21) Gruber: J. Urol., 23, 161, 1930.

22) Hanley: Brit. J. Urol., 34, 283, 1962.

23) Hinman, Miller, Hutch, Gainey, Cox, Goodfriend \& Marshall: J. Urol., 88, 758, 1962.

24) Hodson \& Edwards: Clin. Radiology, 11, 219, 1960.

25) Hoffman \& Bunts: J. Urol., 86, 60, 1961.

26) Hutch: J. Urol., 68, 457, 1952.

27) Hutch: The Ureterovesical Junction, Univ. Calif. Press, Berkeley \& Los Angeles, 1958.

28) Hutch: J. Urol., 88, 354, 1962.

29) Hutch: J. Urol., 89, 180, 1963.

30) Hutch, Hinman \& Miller: J. Urol., 88, 169, 1962.

31) Jeejeebhoy: J. Urol., 88, 506, 1962.

32) 近藤, 梶田, 福島 : 臨外, 16, 331, 1961.

33) 近藤, 梶田, 三木 : 泌尿紀要, 7, 861，1961.

34) 近藤, 内藤, 河田 : 泌尿紀要, 9, 678, 1963.

35) 近藤, 内藤, 河田, 島野: 泌尿紀要, 印刷中.

36) Lapides, Friend, Ajemian \& Reus: J. Urol., 88, 245, 1962.

37) Lattimer, Apperson, Gleason, Baker \& Fleming: J. Urol., 89, 395, 1963.

38) Lich, Howerton \& Davis: J. Urol., 86, 554, 1961.

39) Lowsley \& Porras: Surg. Gynec. \& Obst., 92, 701, 1951.

40) McGovern, Marshall \& Paquin: J. Urol., 83, 122, 1960.

41) Melick \& Naryka: J. Urol., 83, 267, 1960.

42) Melick, Naryka \& Schmidt: J. Urol., 85, 145, 1961.

43) Melick \& Brodeur: J. Urol., 88, 35, 1962.

44) Melick, Brodeur \& Karellos: J. Urol., 88, 38, 1962.

45) Misak, Bunts, Ulmer \& Eagles: J. Urol., 88, 392, 1962.

46) 三沢 : 理療 9 号, 1963.

47) Murnaghan: Brit. J. Urol., 31, 370, 1959.

48) Murphy, Schoenberg \& Tristan: J. Urol., 89, 192, 1963.

49）落合：泌尿器科臨床の為に, 1956, 金原出版, 東京.

50) Palken \& Kennelly: J. Urol., 83, 745, 1960. 
51) Paquin: The Year Book of Urology 19621963, Year Book Medical Publishers

52) Paquin, Marshall \& McGovern: J. Urol., 83, 634, 1960.

53) Politano: J.A.M.A., 172, 1252, 1960.

54) Politano \& Leadbetter: J. Urol., 79, 932, 1958.

55) Ross, Gibbon \& Damanski: Brit. J. Urol., 30, 204, 1958.

56) St. Martin, Campbell \& Pasquier: J. Urol.,
75, 151, 1956.

57) Stephens \& Lenaghan: J. Urol., 87, 669, 1962.

58) Stewart: J. Urol., 70, 588, 1953.

59) Stewart: J. Urol., 74, 749, 1955.

60）辻, 黒田, 藤村: 治療, 46, 511, 1964.

61) Waring: cit. Lowsley \& Kirwin's Clinical Urology, 1958, p. 638.

62) Witherington: J. Urol., 89, 176, 1963. （昭和 39 年 4 月 14 日受付，特別掲載） 